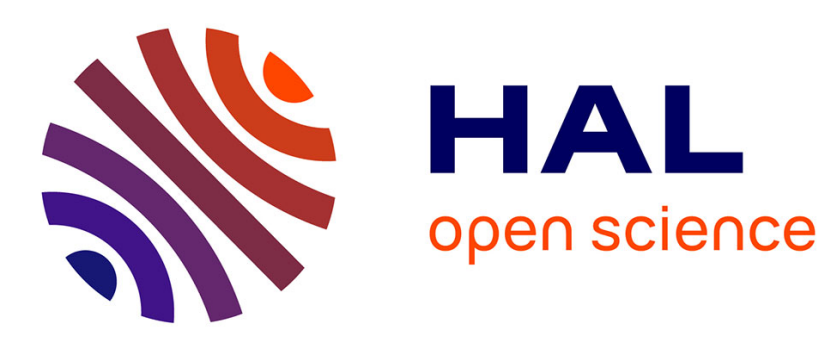

\title{
Specialization, outsourcing and wages
}

Jakob Roland Munch, Jan Rose Skaksen

\section{To cite this version:}

Jakob Roland Munch, Jan Rose Skaksen. Specialization, outsourcing and wages. Review of World Economics, 2009, 145 (1), pp.57-73. 10.1007/s10290-009-0009-2 . hal-00535214

\section{HAL Id: hal-00535214 https://hal.science/hal-00535214}

Submitted on 11 Nov 2010

HAL is a multi-disciplinary open access archive for the deposit and dissemination of scientific research documents, whether they are published or not. The documents may come from teaching and research institutions in France or abroad, or from public or private research centers.
L'archive ouverte pluridisciplinaire HAL, est destinée au dépôt et à la diffusion de documents scientifiques de niveau recherche, publiés ou non, émanant des établissements d'enseignement et de recherche français ou étrangers, des laboratoires publics ou privés. 


\title{
Specialization, outsourcing and wages
}

\author{
Jakob Roland Munch $\cdot$ Jan Rose Skaksen
}

Published online: 6 March 2009

(C) Kiel Institute 2009

\begin{abstract}
This paper studies the impact of outsourcing on individual wages. In contrast to the standard approach in the literature, we focus on domestic outsourcing as well as foreign outsourcing. We argue that if outsourcing is associated with specialization gains arising from an increase in the division of labor, domestic outsourcing tends to increase wages for both unskilled and skilled labor. We use a panel data set of workers in Danish manufacturing industries to show that domestic and foreign outsourcing affect wages as predicted.
\end{abstract}

Keywords Outsourcing - Comparative advantage - Specialization ·

Wages

JEL Classification $\mathrm{F} 16 \cdot \mathrm{J} 31 \cdot \mathrm{C} 23$

\section{Introduction}

The labor market implications of outsourcing of activities to countries abundant in unskilled labor-such as countries in Eastern Europe and Asia-is a topical issue, and the hypothesis seems to be that unskilled workers in Western Europe and the United States have been the losers while skilled workers have gained. This view is supported by empirical evidence showing that the relative demand of unskilled workers in Western Europe and the United States has declined through international specialization (see Feenstra and Hanson (2003) for a survey). This literature is

J. R. Munch

Department of Economics, University of Copenhagen, CEBR, Frederiksberg, Denmark

J. R. Skaksen $(\bowtie)$

Department of Economics, Copenhagen Business School, IZA, CEBR, Frederiksberg, Denmark e-mail: jrs.eco@cbs.dk 
mostly considering how outsourcing affects the relative demand and, in turn, the relative wage of skilled and unskilled labor. The dominating view is that outsourcing is biased towards activities intensive in the use of unskilled labor.

In this paper, we divert attention towards another effect of outsourcing, namely specialization gains that may arise as a result of an increase in the division of labor across firms. International outsourcing may give rise to two types of effects: a comparative advantage effect and a division of labor effect. The comparative advantage effect is due to specialization gains resulting from exploitation of factor endowment differences across countries, and this corresponds to the traditional effect investigated in the literature cited above. The division of labor effect arises if the level of outsourcing within an industry affects the division of labor across firms. This is in line with, e.g., Duranton and Jayet (2005) who argue that the opportunities to reap gains from the division of labor is limited by the extent of the market, and the extent of the market is, in turn, determined by transportation efficiency. It seems plausible that outsourcing is limited by transportation efficiency, and in that case the level of outsourcing will to some extent reflect the division of labor. An important difference between the comparative advantage effect and the division of labor effect is that the comparative advantage effect will be skill biased, and primarily benefit the abundant factor in a country, whereas there is no reason to expect the division of labor effect to be skill biased.

Empirically, it is not straightforward to distinguish between the comparative advantage effect and the division of labor effect, since foreign outsourcing typically gives rise to a mixture of the two effects. This would be the case if, for example, foreign outsourcing in part is composed of activities shifted out to countries with different skill endowments and in part activities outsourced to countries with similar skill endowments. However, in contrast to foreign outsourcing, domestic outsourcing is presumably not skill biased, and domestic outsourcing only affects productivity and wages to the extent that it affects the division of labor. Therefore, in contrast to the usual approach in the literature, we focus on the consequences of foreign as well as domestic outsourcing.

We use data from the Danish labor market, and since Denmark is a skilled labor abundant country, foreign outsourcing is expected to result in comparative advantage effects which benefit skilled labor and hurt unskilled labor. Domestic outsourcing primarily affects wages if there is a division of labor effect. Hence, domestic outsourcing is expected to be more beneficial for unskilled labor than foreign outsourcing, and domestic outsourcing may raise wages for all workers.

The empirical approach is to estimate Mincer human capital wage equations on a panel data set of workers in manufacturing industries combined with industry level data on outsourcing for the period 1993-2002. That is, we exploit variation in outsourcing over time and across industries to identify the effects of industry level outsourcing on individual wages. Thus we implicitly take a short run view of the economy since the labor market must clear on an industry by industry basis for inter-industry wage differentials to exist. Such industry wage differences are consistent with empirical evidence. For example for the US economy, controlling for labor characteristics, Katz and Summers (1989) have found significant inter-industry wage differences. Unlike the vast majority of 
papers studying the labor market implications of outsourcing, our approach controls for individual heterogeneity and we are in position to correct for potential endogeneity of outsourcing variables.

Our estimation results offer strong support for the hypothesis that outsourcing has comparative advantage effects as well as division of labor effects. We find that foreign outsourcing reduces wages for low-skilled workers, while wages of highskilled workers rise. In contrast, domestic outsourcing tends to increase wages for low and medium-skilled workers, while there is no significant effect on high-skilled wages.

Our empirical approach is closely related to Geishecker and Görg (2008). They study the implications of foreign outsourcing on individual wages in a human capital framework by using data on a large German household panel combined with industry level data for the period 1991-2000. In line with our results, they find that foreign outsourcing generally reduces wages of low-skilled workers and increases wages of high-skilled workers. However, by using information on domestic outsourcing, we find that outsourcing also entails a division of labor effect, and this effect may be very different from the comparative advantage effect usually focused on in the literature.

The paper is structured as follows. In the following section we discuss the theoretical link between outsourcing and wages, and we present the hypotheses to be tested empirically. In Sect. 3 we describe the data. The empirical model is specified in Sect. 4, and Sect. 5 presents the results. Finally, Sect. 6 concludes.

\section{Outsourcing, productivity and wages}

Two different lines of the literature have considered the labor market implications of specialization on the one hand and international outsourcing on the other. In The Wealth of Nations, Adam Smith famously argued that specialization gains are realized in larger markets by increasing the division of labor, and an immediate consequence is that workers should be able to command higher wages in larger markets. This key insight was later formalized by Ethier (1982), who showed that intra-industry trade in differentiated intermediate goods can arise because firms find it profitable to split up their production processes. That is, a larger number of intermediate goods become available from opening up for trade, and this increases the productivity of final goods producers. ${ }^{1}$ This insight is theoretically well understood, but as noted by Duranton and Jayet (2005) there is remarkably little empirical work on the division of labor. ${ }^{2}$ In their empirical analysis they focus on the link between the extent of the market and the division of labor, and they find a positive relationship between division of labor and the size of French cities. In contrast, the link between the division of labor and wages, which is the subject of

\footnotetext{
${ }^{1}$ Ethier's division of labor model has since found numerous applications in, e.g., international trade, growth theory and development. For a recent coherent exposition of this model and its variants, see Francois and Nelson (2002). Becker and Murphy (1992) argue that the level of specialization also depends on other considerations such as various coordination costs.

2 Duranton and Jayet (2005) cite two case studies that focus on particular industries.
} 
our paper, is still an empirically unexplored issue. That international outsourcing, on the other hand, may reduce the relative wages of unskilled workers has been documented in a series of papers by Feenstra and Hanson (see, e.g., Feenstra and Hanson (2003)). However even in the case where unskilled intensive production activities are moved abroad it is possible that unskilled labor may benefit because outsourcing also entails cost savings for domestic industries as shown by Arndt (1997) and Kohler (2004).

In the empirical analysis below it is not possible to distinguish between international outsourcing that leads to comparative advantage effects and international outsourcing with division of labor effects. Therefore, we exploit information on domestic outsourcing as well as foreign outsourcing in our analyses. We apply data from Denmark which is a small and homogenous country. Hence, if domestic outsourcing affects productivity and wages, this is likely to be because of division of labor effects and not comparative advantage effects. In other words, the comparative advantage effects are stronger in international outsourcing than in domestic outsourcing. This gives rise to the following hypotheses to be tested in the following sections ${ }^{3}$ :

Hypothesis 1 Since Denmark is a high-skilled labor-intensive country, the comparative advantage effects implies that international outsourcing benefits highskilled labor more than low-skilled labor.

Hypothesis 2 Domestic outsourcing as well as foreign outsourcing have division of labor effects, but there are no comparative advantage effects from domestic outsourcing. Therefore, domestic outsourcing have similar effects on low-skilled labor and high-skilled labor.

\section{Data}

To test our hypotheses we need information on the absolute wage level of different types of workers. We have access to a panel data set of workers in Danish manufacturing industries for the years 1993-2002, and to this data set we add measures of outsourcing at the industry level.

We measure domestic and foreign outsourcing in terms of intermediate inputs in production at the industry level (55 manufacturing industries based on a Danish industry code which is between the two-digit and three-digit NACE definition). Feenstra and Hanson (1996) and Feenstra and Hanson (1999) consider two different measures for foreign outsourcing - a broad and a narrow measure. The broad measure is defined as the value of all imported intermediate inputs of an industry, while the narrow measure restricts attention to intermediate inputs that are purchased from the same industry as the good being produced. The idea behind the narrow measure is that it only includes imported intermediate goods that could have been produced within the domestic industry, so this measure arguably best captures

\footnotetext{
3 These hypotheses are straightforward to derive from a model building on Ethier (1982), see Munch and Skaksen (2005).
} 


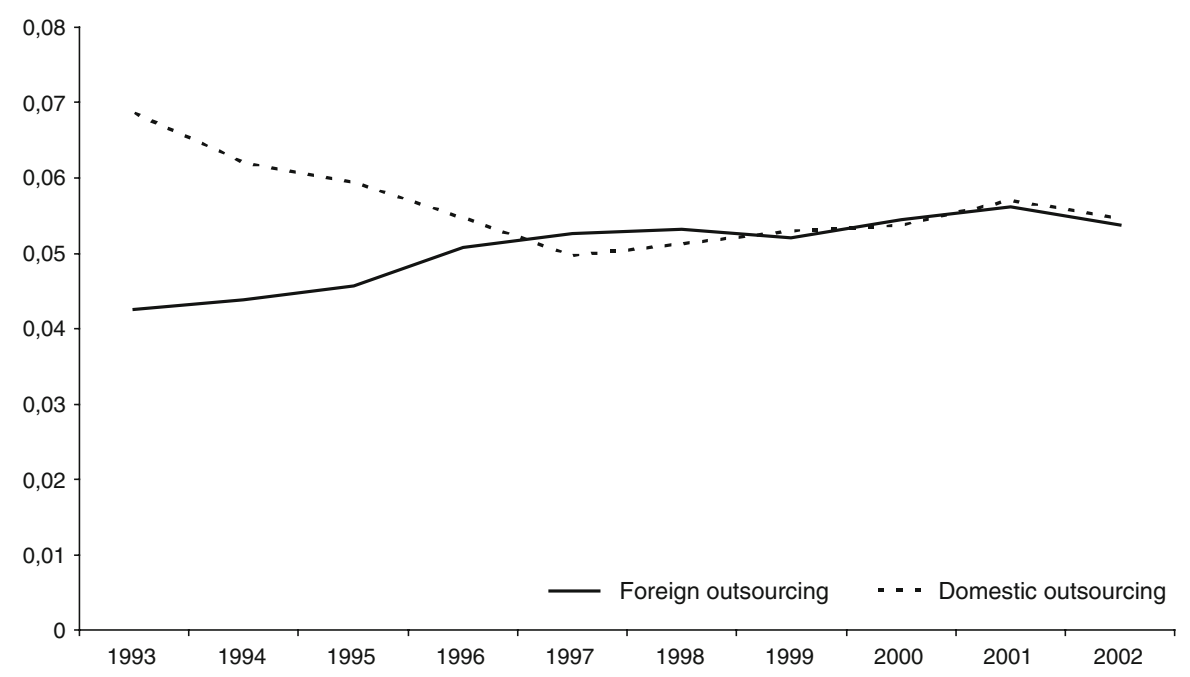

Fig. 1 Foreign and domestic outsourcing in Danish manufacturing industries

the idea of specialization within the industry. We consider only the narrow measure of foreign outsourcing, and in a similar way a narrow measure of domestic outsourcing can be defined. This measure of domestic outsourcing is then capturing the degree of division of labor at the industry level, if domestic outsourcing is limited by transportation efficiency (and thus the extent of the market) within the industry.

The domestic and foreign measures are constructed from annual input-output tables from Statistics Denmark. It should be noted that the Danish input-output tables have an explicit distinction between intermediate purchases from domestic and foreign suppliers. We follow Hijzen et al. (2005) among others, and define outsourcing as intermediate goods divided by industry output. Figure 1 shows the measures of domestic and foreign outsourcing as a weighted average for all manufacturing industries. As expected foreign outsourcing has become more important during the period, while domestic outsourcing declined in the beginning of the period.

To get a picture of the importance of outsourcing across industries Figs. 2 and 3 plot foreign and domestic outsourcing for six different subgroups of industries. ${ }^{4}$ For foreign outsourcing it is seen that 'Textiles' and 'Electric machinery' have a relatively high level of outsourcing and these industries also experienced the highest rise in outsourcing. In contrast 'Wood and paper' had a declining foreign outsourcing intensity during the sample period. The two groups of industries with the highest levels of domestic outsourcing are 'Wood and paper' and 'Electric machinery'. It should be noted that 'Wood and paper' include disaggregated

\footnotetext{
${ }^{4}$ Industry groups are defined using the two-digit NACE code; Textiles (17-19), Wood and paper (20-22), Metal and machinery (27-29), Electric machinery (30-33), Transport (34-35), and Other $(15-16,23-26,36)$.
} 


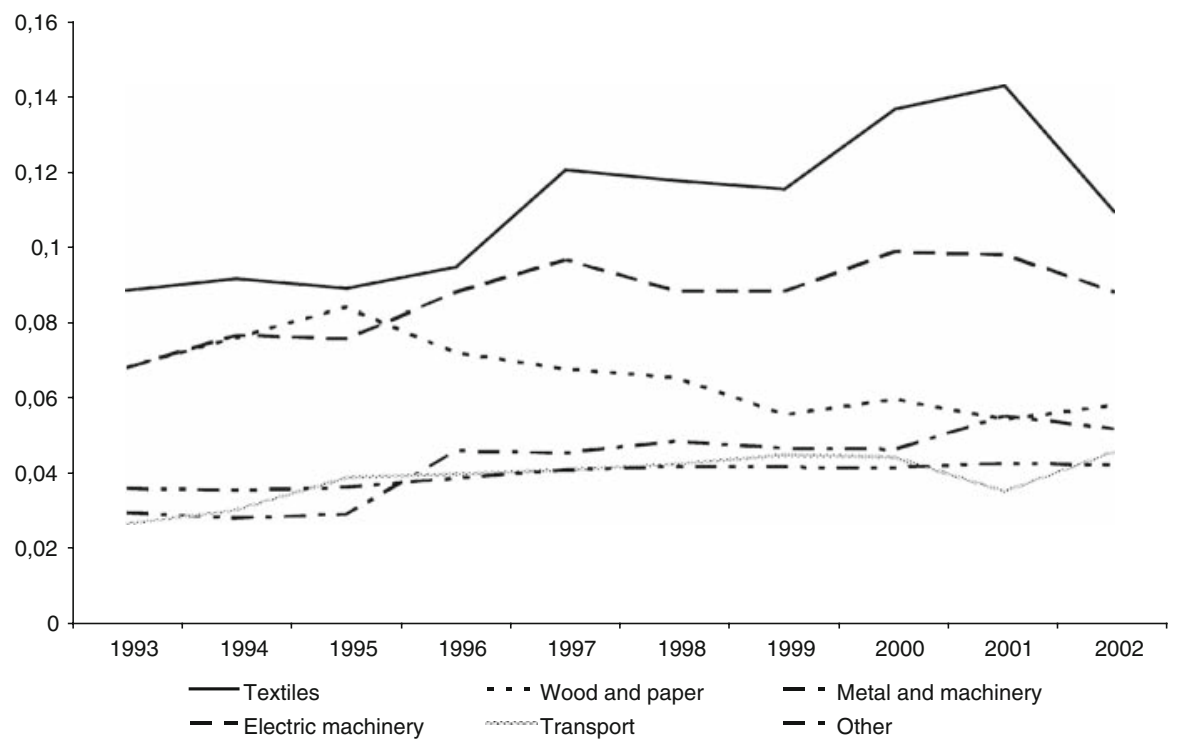

Fig. 2 Foreign outsourcing in broad industry groups

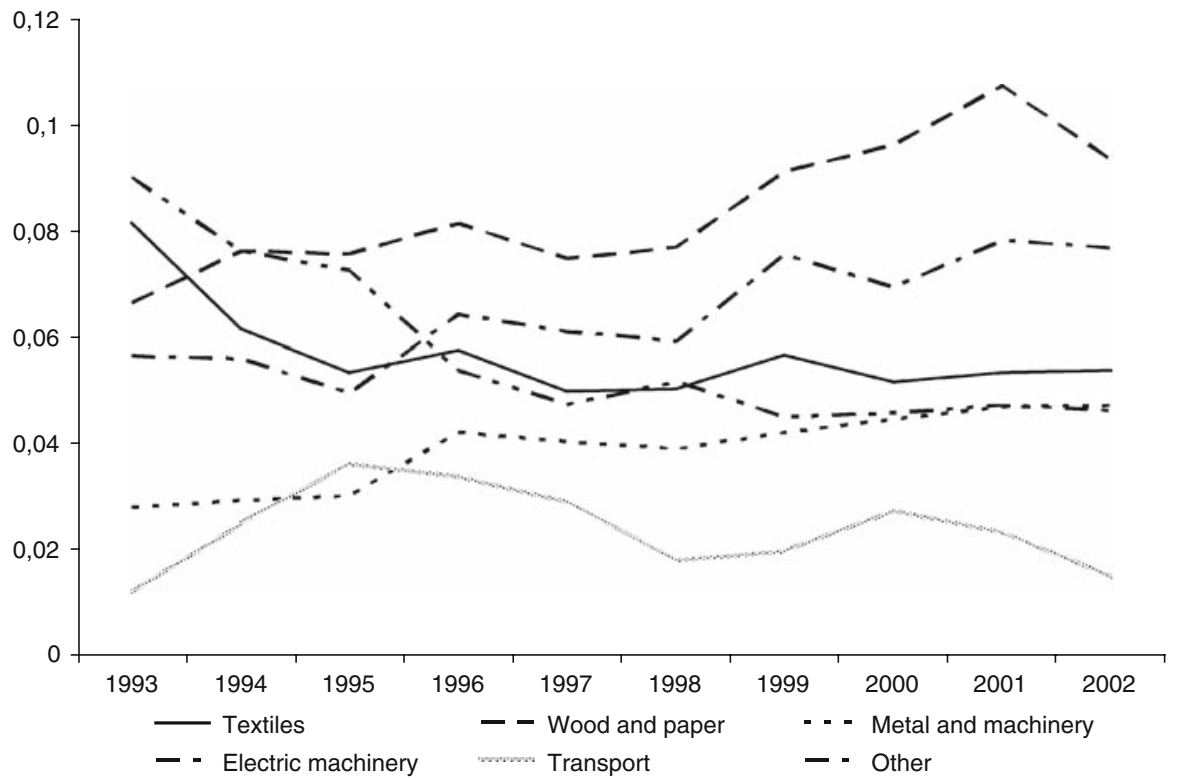

Fig. 3 Domestic outsourcing in broad industry groups 


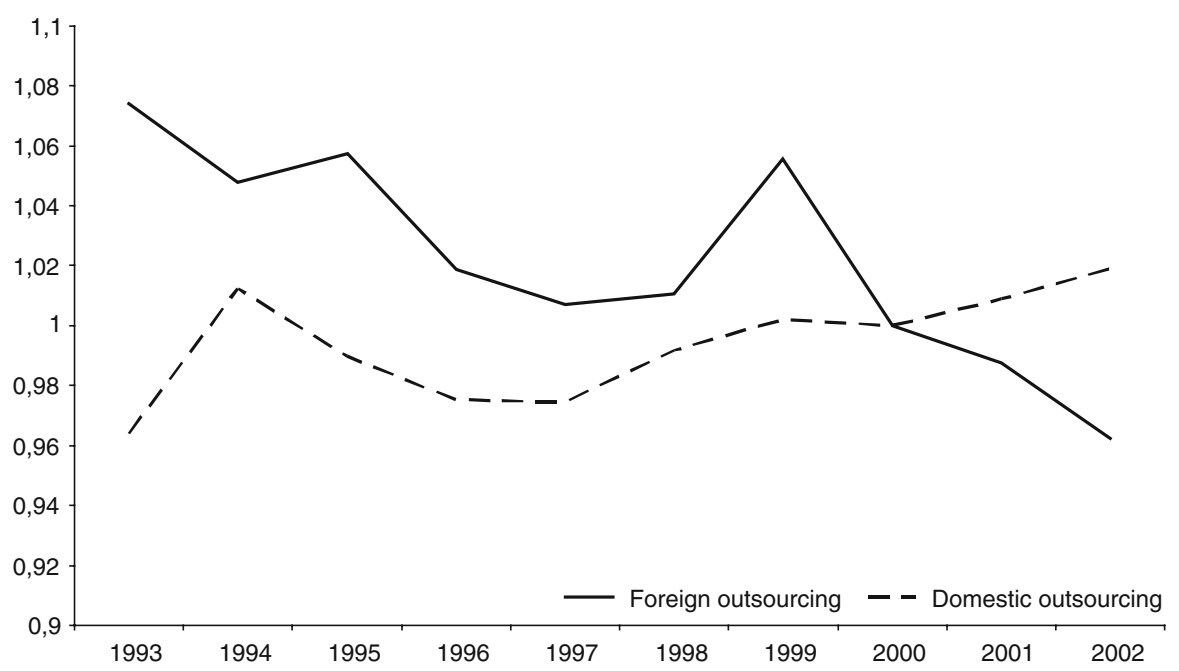

Fig. 4 Relative prices of foreign and domestic outsourcing

industries such as printing and service activities related to printing, and publishing of newspapers both with relatively high domestic outsourcing intensities. This indicates that domestic outsourcing is more widespread in service-based industries.

Finally, we also construct a measure for the price of outsourcing to be used as an instrumental variable in the empirical analysis. We exploit the fact that the inputoutput tables are available in both fixed and current prices. That is, a measure of the price of, e.g., imported intermediates in a given industry may be calculated as the value of imported intermediates in current prices divided by the value of imported intermediates in fixed (2000) prices. In the following we measure the price of foreign (narrow) outsourcing in the industry relative to the corresponding price of output in the industry. This gives us a measure of the price of imported intermediates relative to the price of domestic output. Likewise we construct a measure of the relative price of domestic outsourcing as the price of domestic intermediates used in production in the industry divided by the price of output in the industry. Figure 4 displays these relative price measures for foreign and domestic outsourcing for the entire manufacturing sector, and, as expected, the price of foreign outsourcing has declined (by more than 10\% from 1993 to 2002), while the price of domestic outsourcing has been roughly constant.

There may be other industry variables than outsourcing affecting wages of different types of labor. In particular the relative employment of different types of labor may be important. To take this into account we include the industry share of workers with vocational education, and the share with further education (the reference is basic education). Also the ratio of capital to labor may affect wages. To accommodate for this, we include a variable measuring the total industry payment to capital relative to labor. 
We also include industry export and import. The export activity is likely to be correlated with firm productivity (see, e.g., Bernard et al. (2003)) and could thus affect wages. A higher level of import penetration is likely to increase competition and reduce rents and wages. In addition, the size of the industry in terms of the value of production is included to capture other unobserved industry characteristics. Finally, a full set of year dummies is included to capture business cycle effects.

Information about individual characteristics of a $10 \%$ sample of workers in Danish manufacturing is extracted from the integrated database of labor market research (IDA) and the Income Registers in Statistics Denmark. ${ }^{5}$ The hourly wage rate is clearly the most important individual level variable in the analysis, and this wage rate is calculated as total labor income divided by the total number of hours worked in any given year. A few problems are encountered when using this IDAwage rate. Most importantly, the measure for total labor income as such is highly reliable since it comes from the tax authorities, but it does not include mandatory pension fund payments. These payments were introduced in the early 1990s, and have been rising throughout the sample period but not in a uniform manner across collective bargaining segments of the labor market. However, since the individual annual pension fund payments are available in the data, it was straightforward to correct the wage rate. Also, a measurement error could arise as potential overtime work is not included in the registered number of hours worked.

A long list of individual socio economic characteristics are used as control variables in the analysis. Of particular interest is information about education and occupation. The classification of education groups relies on a Danish education code and the variable 'Further education' basically corresponds to the two highest categories (5 and 6) in the international standard classification of education (ISCED), i.e., the individual has a tertiary education. 'Vocational education' is defined as the final stage of secondary education encompassing programs that prepare students for direct entry into the labor market. Thus persons with just high school or equivalent are not included in this category and are classified as workers with just 'Basic education'. Information about individual occupation is based on the Danish version of the ISCO-88 definition, and we operate with the nine main categories.

Among other socio economic characteristics are self explanatory dummies for gender, the presence of children, the presence of two adults in the household, city size, experience and tenure. ${ }^{6}$ There are also dummies for membership of unemployment insurance funds and trade unions, and there are dummies for the size of the firm (or more precisely workplace) in terms of the workforce.

We restrict the sample to include only full-time manufacturing workers in the age group of 18-65 years. In the final data set there are 356,139 observations coming from 71,105 workers. Descriptive statistics for a selected set of variables are presented in Table 1.

\footnotetext{
5 For more details on the IDA data see Abowd and Kramarz (1999).

${ }^{6}$ Information about workplace tenure only goes back to 1980 , so an indicator variable for left censored tenure is included.
} 
Table 1 Summary statistics

\begin{tabular}{|c|c|c|c|}
\hline Variables & Mean & Min. & Max. \\
\hline Log wage rate (DKR) & 5.1675 & 3.6842 & 6.8093 \\
\hline Female & 0.2775 & 0.0000 & 1.0000 \\
\hline Married & 0.5694 & 0.0000 & 1.0000 \\
\hline Two adults & 0.7363 & 0.0000 & 1.0000 \\
\hline Children $0-6$ years & 0.2239 & 0.0000 & 1.0000 \\
\hline Experience (years) & 16.9764 & 0.0580 & 39.0000 \\
\hline Tenure (years) & 5.3428 & 0.0000 & 22.0000 \\
\hline Censored tenure & 0.0824 & 0.0000 & 1.0000 \\
\hline Basic education & 0.4554 & 0.0000 & 1.0000 \\
\hline Vocational education & 0.3914 & 0.0000 & 1.0000 \\
\hline Further education & 0.1531 & 0.0000 & 1.0000 \\
\hline Union member & 0.8336 & 0.0000 & 1.0000 \\
\hline UI fund member & 0.9254 & 0.0000 & 1.0000 \\
\hline Firm size $0-10$ & 0.0626 & 0.0000 & 1.0000 \\
\hline Firm size $11-50$ & 0.2167 & 0.0000 & 1.0000 \\
\hline Firm size $51-200$ & 0.3111 & 0.0000 & 1.0000 \\
\hline Firm size 200 and more & 0.4095 & 0.0000 & 1.0000 \\
\hline Copenhagen & 0.1271 & 0.0000 & 1.0000 \\
\hline Big cities & 0.1272 & 0.0000 & 1.0000 \\
\hline Rest of country & 0.7457 & 0.0000 & 1.0000 \\
\hline \multicolumn{4}{|l|}{ Industry characteristics } \\
\hline Capital labor ratio & 3.0546 & 0.2233 & 77.0730 \\
\hline Basic education share & 0.3808 & 0.0822 & 0.6364 \\
\hline Vocational education share & 0.4656 & 0.1667 & 0.6557 \\
\hline Further education share & 0.1536 & 0.0377 & 0.6667 \\
\hline Import ratio & 0.6452 & 0.0083 & 9.8199 \\
\hline Export ratio & 0.6013 & 0.0083 & 3.0107 \\
\hline Production value (billion DKK/100) & 0.1516 & 0.0046 & 0.4898 \\
\hline Foreign outsourcing & 0.0515 & 0.0000 & 0.2838 \\
\hline Domestic outsourcing & 0.0524 & 0.0001 & 0.1906 \\
\hline Foreign outsourcing price & 1.0179 & 0.5502 & 3.4972 \\
\hline Domestic outsourcing price & 0.9952 & 0.2518 & 2.0579 \\
\hline Number of observations & 356,139 & & \\
\hline
\end{tabular}

\section{Empirical model}

The empirical strategy is to test the hypotheses outlined in Sect. 2 by estimating a simple Mincer human capital wage equation of the form

$$
\log w_{i j t}=\beta^{\prime} x_{i t}+\gamma^{\prime} z_{j t}+\alpha_{i}+\epsilon_{i j t},
$$

where $w_{i j t}$ is the hourly wage of worker $i$ in industry $j$ at time $t$. Individual covariates such as experience, experience squared and tenure are included in $x_{i t}$, 
and industry-specific variables - notably outsourcing variables-are contained in $z_{j t}$. Individual unobserved heterogeneity is controlled for by estimating a fixed effects version of the wage equation - a random effects model was rejected in a standard Hausman specification test.

When estimating the effects of aggregate variables (i.e., outsourcing at the industry level) on micro units (individual workers), the standard errors of the estimated coefficients are biased downward in OLS regressions. We account for such clustering of individuals within industries by adjusting the standard errors along the lines of Moulton (1990).

Another potentially important methodological issue merits careful consideration. The coefficients to our variables of interest (i.e., the two outsourcing variables) may be plagued by endogeneity bias, because it could be argued that outsourcing not only affects individual wages, but that wages also to some extent drive outsourcing decisions. This may in particular be the case for foreign outsourcing. As argued by, e.g., Geishecker and Görg (2008) potential endogeneity problems are less of a concern when regressing individual wages on industry level variables, since the industry's outsourcing intensity may be largely considered exogenous to the individual worker. But even so outsourcing may still be endogenous if just a small part of individual wages is an industry specific component. This would for instance be a concern if wages partially are set in industry level wage negotiations as is often the case in unionized labor markets. We address this issue by instrumenting the outsourcing measures in (1).

Proper implementation of instrumental variables methods requires acceptable instruments. First, they should be relevant, i.e., they should explain a significant amount of variation in the endogenous regressors. Second, they must be valid in the sense that they are uncorrelated with the error term in the wage equation. We are in a situation where we have multiple potentially plausible instruments for each outsourcing variable (see below), so our strategy is in each model as a first step to include all potential instruments implementing 2SLS, since this may generate more efficient estimates.

We evaluate the relevance of instruments in a number of ways. First, we successively implement the test of redundancy suggested by Hall and Peixe (2003) for each instrument. Instruments are redundant if the asymptotic efficiency of the estimation is not improved by using them, and any redundant instruments are removed by this procedure. Second, for the final set of instruments we calculate the cluster-robust $F$-test for excluded instruments corresponding to the "partial $R$-squared" measure of instrument relevance proposed by Bound et al. (1995). This is a test for joint significance of the instruments in the first stage regression. Finally, we also calculate the Cragg-Donald $F$-statistic suggested by Stock and Yogo (2005) for the presence of weak instruments (the null is that the equation is underidentified). We never found any signs of redundancy, irrelevance or weakness of any of our instruments in any model below.

With respect to the validity requirement we first test each instrument individually using the $C$-statistic (see, e.g., Hayashi (2000)) by choosing a relatively conservative significance level of $20 \% .^{7}$ That is, if we reject the null hypothesis

\footnotetext{
7 We also used the $10 \%$ significance level, but it made almost no difference in the results.
} 
that the excluded instrument is valid at the $20 \%$ level this instrument is dropped from the list of instruments. ${ }^{8}$ For all the remaining valid instruments we also evaluate their overall validity and show the $p$-value of the Hansen $J$-statistic ${ }^{9}$ for the joint null hypothesis that they are valid. Finally, we also calculate and report the cluster-robust version of the Hausman test of endogeneity (again see, e.g., Hayashi (2000)) of the two outsourcing variables in the model with the final set of instruments. The null hypothesis is that the outsourcing variables are exogenous.

As explained in the data section we have constructed a measure of the price of outsourcing (both domestic and foreign), and since the data source for the outsourcing variables (the input-output tables) goes back to 1966 we can use lagged prices and lagged outsourcing levels as instruments. If prices of intermediate goods are determined in international markets they can reasonably be taken as exogenous to the wage equation. Of course, prices of outsourcing should influence the amount outsourced, so a priori prices qualify as potential instruments. It may be argued that also lagged prices matter since it may take time to establish contacts to suppliers and to adjust the internal organization of the firm to accommodate outsourcing. For this reason we include prices of foreign and domestic outsourcing along with their 1 -year and 3-year lagged values in the list of potential instruments. The 10-year and 20 -year lagged values of foreign and domestic outsourcing levels are also included in the list, as historical values of outsourcing should be exogenous to present day labor market outcomes. Thus the full set of potential instrument count 10 variables.

\section{Results}

The results of estimating different versions of the wage Eq. (1) for the full sample are presented in Table 2. To sweep out individual fixed effects we first mean difference the data, and to control for observed individual heterogeneity we include all the individual covariates displayed in Table 2. Their estimated coefficients are not reported, but for all three models of the table, they have expected signs; i.e., labor market experience, tenure and education are positively related to wages. There appears to be no wage effect of union membership whereas there is a positive wage premium associated with being insured against unemployment. There is also a significant firm size effect, which is consistently found in the literature (see, e.g., Oi and Idson (1999)).

With the purpose to investigate the importance of controlling for different industry characteristics, model 1 only includes the outsourcing measures. It appears that foreign outsourcing has a negative but insignificant effect on wages, while domestic outsourcing has a significantly positive effect. Thus, in line with our second hypothesis in Sect. 2, domestic outsourcing seems to raise individual wages, presumably as a result of specialization gains. These effects are almost unaffected

\footnotetext{
${ }^{8}$ If more than one instrument fails the $C$-test with the full set of instruments, we mechanically select the first instrument to be dropped from the list by picking the one with the lowest $p$-value. Next, the $C$-test is computed again for all remaining instruments and we drop the one with the lowest $p$-value provided this value is below $20 \%$ and so on.

9 The Hansen $J$-statistic is a cluster-robust version of Sargan's statistic for overidentification.
} 
Table 2 Estimation results, full sample

\begin{tabular}{|c|c|c|c|c|c|c|}
\hline \multirow[t]{2}{*}{ Variables } & \multicolumn{2}{|l|}{ Model 1} & \multicolumn{2}{|l|}{ Model 2} & \multicolumn{2}{|l|}{ Model 3} \\
\hline & Coeff. & Std.err. & Coeff. & Std.err. & Coeff. & Std.err. \\
\hline Production value & & & 0.0554 & 0.0284 & -0.0600 & 0.0758 \\
\hline Import ratio & & & 0.0040 & 0.0023 & -0.0002 & 0.0040 \\
\hline Export ratio & & & -0.0105 & 0.0077 & 0.0069 & 0.0155 \\
\hline Voc. edu. share & & & -0.0297 & 0.0360 & -0.0100 & 0.0447 \\
\hline Further edu. share & & & 0.0936 & 0.0349 & 0.1140 & 0.0411 \\
\hline Capital labor ratio & & & 0.0024 & 0.0008 & 0.0018 & 0.0006 \\
\hline Foreign outsourcing & -0.0426 & 0.0407 & -0.0486 & 0.0373 & -0.0327 & 0.0747 \\
\hline Domestic outsourcing & 0.3515 & 0.0717 & 0.2941 & 0.0601 & 0.7405 & 0.2692 \\
\hline Individual fixed effects & Yes & & Yes & & Yes & \\
\hline Method & OLS & & OLS & & 2SLS & \\
\hline Cragg-Donald $F$-statistic & & & & & 1,808 & \\
\hline$p$-value of partial $R^{2} F$-test (foreign) & & & & & 0.0000 & \\
\hline$p$-value of partial $R^{2} F$-test (domestic) & & & & & 0.0001 & \\
\hline$p$-value of Hansen $J$-stat & & & & & 0.7423 & \\
\hline$p$-value of endog. test & & & & & 0.1645 & \\
\hline No. of observations & 342,081 & & 342,081 & & 342,081 & \\
\hline$R^{2}$ (within) & 0.2882 & & 0.2891 & & 0.2868 & \\
\hline
\end{tabular}

Robust standard errors adjusted for clustering at industry level are reported next to coefficients. Bold numbers indicate significance at the 5\% level. All models include the individual level variables listed in Table 1, occupation dummies and year dummies

by the introduction of the full set of industry variables in model 2. Only the share of workers in the industry with further education and the capital labor ratio enters the model with significant effects. The insignificant effects of imports and exports in the industry are in contrast to the results of Edin et al. (2004) who study the Swedish labor market. They find that foreign competition in the form of the import penetration has a negative effect on wages, while there is a wage premium for workers employed in industries that tend to export a high share of their production.

In model 3 we investigate the potential endogeneity of the outsourcing variables by implementing instrumental variables regression. Only one instrument (domestic outsourcing lagged 20 years) failed the validity requirement at the $20 \%$ level, so the final model has nine excluded instruments. With this specification the qualitative impact of outsourcing does not change; foreign outsourcing still has a small insignificant negative effect on wages, and domestic outsourcing has a positive impact, but the coefficient is more than doubled in size. Clearly, according to the Hansen $J$-test we cannot reject the null that the instruments are jointly valid, but the endogeneity test shows that we cannot reject the null of exogenous outsourcing variables either. Thus overall we conclude that foreign outsourcing has small insignificant negative effect on wages while domestic outsourcing has a positive effect - the point estimates means that a one percentage point increase in domestic outsourcing corresponds to between $0.29 \%$ (model 2 ) and $0.74 \%$ (model 3 ) higher wages. 
In the first hypothesis in Sect. 2 it is stated that foreign outsourcing is likely to be biased towards activities intensive in unskilled labor. As a result foreign outsourcing should benefit skilled labor, while it is ambiguous how wages of unskilled labor are affected. With respect to domestic outsourcing, if it corresponds to a pure division of labor effect in the sense that there is no skill bias, we expect that more domestic outsourcing leads to higher wages for all workers. If instead there is skill bias in domestic outsourcing then it should clearly be less biased towards activities intensive in unskilled labor than foreign outsourcing since Denmark is a skilled labor abundant country. In that case all we can say is that domestic outsourcing should benefit unskilled workers more than foreign outsourcing, and it should benefit skilled workers less than foreign outsourcing.

To study these questions we have estimated the model for workers with three different levels of education: basic education, vocational education and further education (see Table 3). For each educational subgroup we report both the OLS results and the results of the 2SLS instrumental variables regression (corresponding to model 2 and 3 above). ${ }^{10}$ We find that foreign outsourcing harms workers with basic education, but workers with further education gain from this type of outsourcing (which is in line with the main result of Geishecker and Görg (2008)). For workers with basic education the coefficient to foreign outsourcing is almost unchanged by correcting for potential endogeneity, and according to the endogeneity test the outsourcing variables can be treated as exogenous. In contrast, there are signs that foreign outsourcing is endogenous to wages of high-skilled workers and correction for this implies that the positive coefficient to foreign outsourcing more than doubles. Thus, there appears to be solid evidence that foreign outsourcing benefits workers with further education, while there is a negative impact on wages of workers with just basic education. With respect to the quantitative importance of these effects a $1 \%$ point increase in foreign outsourcing leads to between 0.14 and $0.31 \%$ higher wages for workers with further education and $0.11 \%$ lower wages for workers with basic education.

Turning to the effects of domestic outsourcing, workers with basic and vocational education benefit, while there is a positive but insignificant impact on wages of workers with further education. Domestic outsourcing appears not to correspond to a pure division of labor effect. Instead the results suggest that it is slightly biased towards skilled labor as there is no effect on high skilled wages. ${ }^{11}$

In a final sensitivity analysis we divide the sample into male and female workers since wage determination may be quite distinct for these two groups. While domestic outsourcing has roughly the same positive impact on male and female workers, we do indeed find that foreign outsourcing tend to influence men and women differently. Male workers do not seem to be affected by foreign outsourcing, but women appear to be negatively affected (see Table 4).

\footnotetext{
${ }^{10}$ The final specifications of the three instrumental variables regressions contains 8 or 9 excluded instruments after dropping invalid instruments.

11 If instead we only use two skill groups by combining basic education and vocational education into one group (to keep in line with much of the literature) we get roughly the same results. In the 2SLS model domestic outsourcing has a significant positive impact on low skilled wages (the coefficient is 0.8195), and foreign outsourcing has an insignificant negative effect (the coefficient is -0.0593 ).
} 


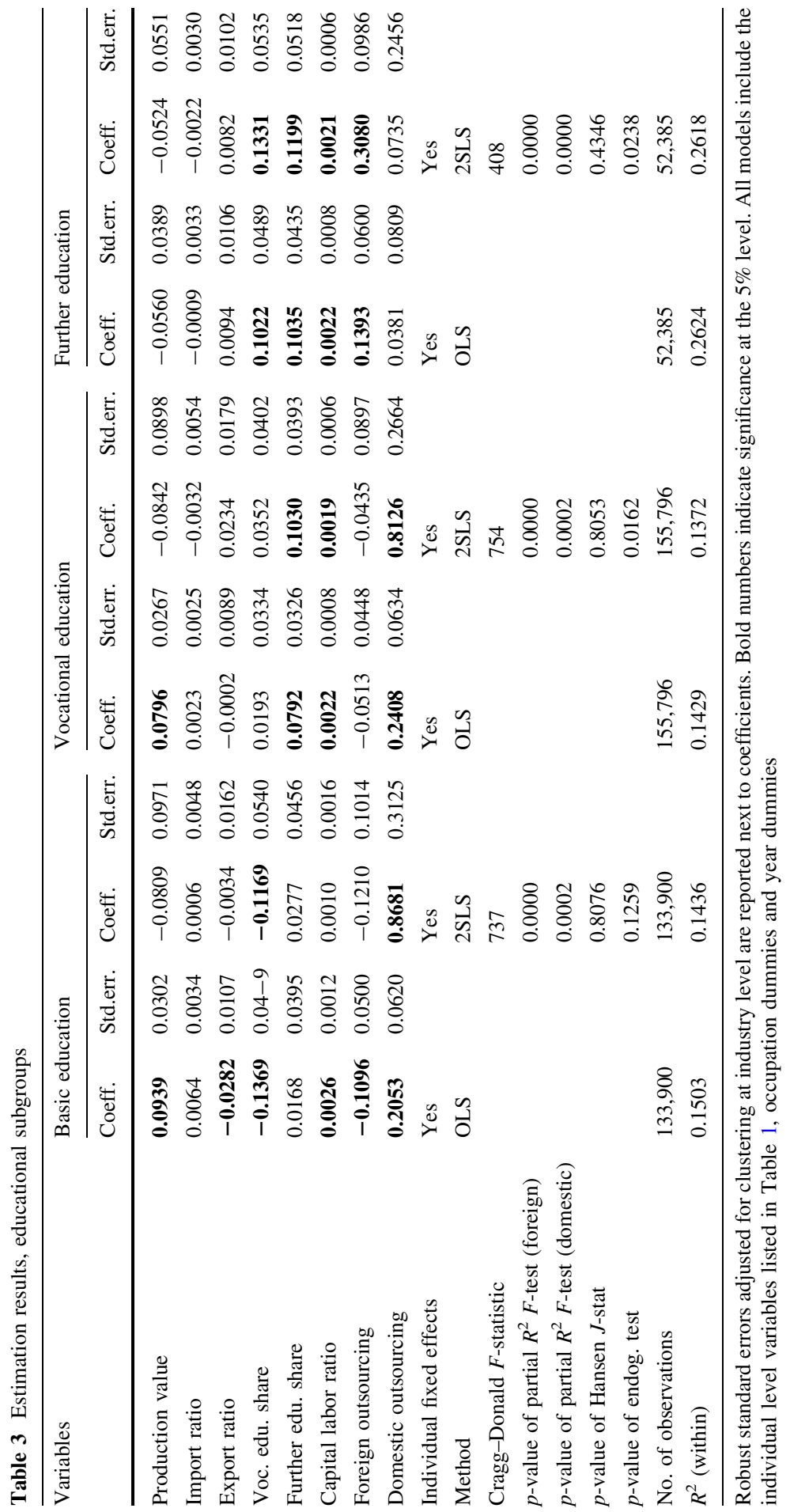




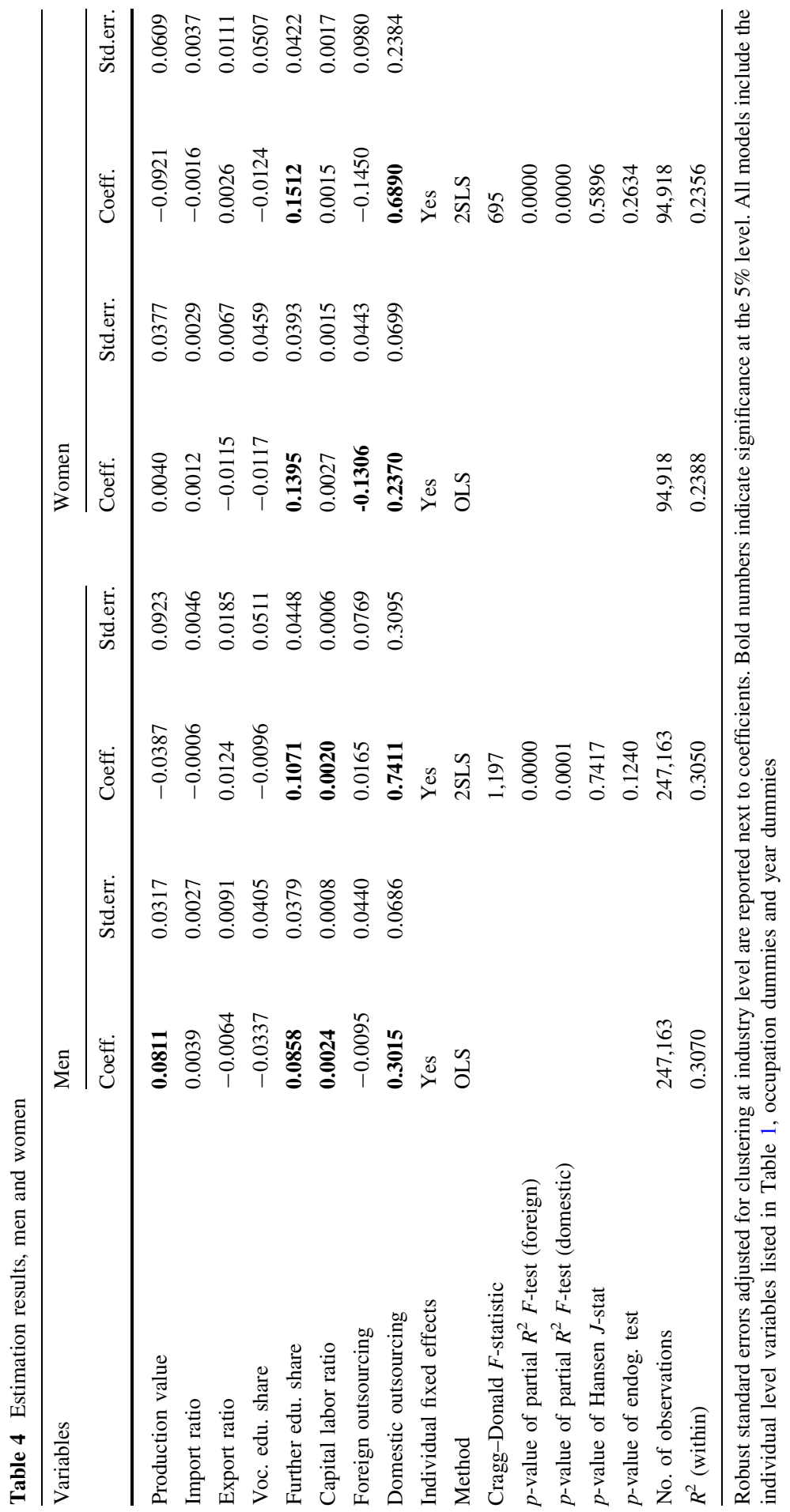




\section{Conclusion}

The standard approach in the literature on wages and outsourcing is to focus entirely on the consequences of foreign outsourcing. In this paper, we have diverted attention towards the consequences of domestic outsourcing, such that the implications of both types of outsourcing can be analyzed.

We have argued that, in general, outsourcing is associated with specialization gains arising from an increase in the division of labor. If domestic outsourcing has no bias towards any type of labor, it corresponds to a pure division of labor effect, and it increases wages for all workers. In contrast, in highly developed countries, foreign outsourcing is expected to be biased towards activities intensive in unskilled labor. Therefore, foreign outsourcing benefits skilled labor more than unskilled labor, and it is likely that unskilled wages are decreasing in the level of foreign outsourcing.

By using data on the Danish labor market, we show that domestic outsourcing as well as foreign outsourcing do affect wages. We find that international outsourcing tends to raise wages of workers with further education and lower wages of workers with basic and vocational education. In contrast, we find that domestic outsourcing tends to raise wages of workers with basic and vocational education, while domestic outsourcing has no significant impact on wages for workers with further education.

In this paper, we have considered domestic outsourcing and foreign outsourcing. An interesting extension in future research would be to subdivide foreign outsourcing into groups of destination countries according to their relative labor endowment. We would expect that outsourcing to countries having a similar relative factor endowment as the domestic economy mainly affects wages through an increase in the extent of the market for intermediate goods, and therefore benefits all types of labor. The comparative advantage effect is expected to be much more important when considering outsourcing to countries with a very different factor endowment, and outsourcing to these countries may hurt unskilled labor.

Acknowledgments Financial support from the Danish Social Science Research Council is gratefully acknowledged. The paper has benefitted from comments from seminar participants at Department of Economics, Aarhus University and Economic Policy Research Unit, University of Copenhagen.

\section{References}

Abowd, J. M., \& Kramarz, F. (1999). The analysis of labor markets using matched employer-employee data. In O. Ashenfelter, \& D. Card (Eds.), Handbook of labor economics Vol. III. Amsterdam: North Holland.

Arndt, S. W. (1997). Globalization and the open economy. North American Journal of Economics and Finance, 8, 71-79.

Becker, G. S., \& Murphy, K. (1992). The division of labor, coordination costs and knowledge. Quarterly Journal of Economics, 107, 1137-1160.

Bernard, A. B., Eaton, J., Jensen, J. B., \& Kortum, S. (2003). Plants and productivity in international trade. American Economic Review, 93, 1268-1290.

Bound, J., Jaeger, D. A., \& Baker, R. (1995). Problems with instrumental variables estimation when the correlation between the instruments and the endogeneous explanatory variable is weak. Journal of the American Statistical Association, 90, 443-450. 
Duranton, G., \& Jayet, H. (2005). Is the division of labour limited by the extent of the market? Evidence from French cities. CEPR Discussion Paper No. 5087.

Edin, P.-A., Frederiksson, P., \& Lundborg, P. (2004). The effect of trade on earnings-evidence from Swedish micro data. Oxford Economic Papers, 56, 231-241.

Ethier, W. J. (1982). National and international returns to scale in the modern theory of international trade. American Economic Review, 72, 389-405.

Feenstra, R. C., \& Hanson, G. H. (1996). Globalization, outsourcing, and wage inequality. American Economic Review, 86, 240-245.

Feenstra, R. C., \& Hanson, G. H. (1999). The impact of outsourcing and high-technology capital on wages: estimates for the United States, 1979-1990. Quarterly Journal of Economics, 114, 907-940.

Feenstra, R. C., \& Hanson, G. H. (2003). Global production sharing and rising inequality: a survey of trade and wages. In E. K. Choi, \& J. Harrigan (Eds.), Handbook of international trade, Malden: Blackwell.

Francois, J. F., \& Nelson, D. (2002). A geometry of specialisation. Economic Journal, 112, 649-678.

Geishecker, I., \& Görg, H. (2008). Winners and losers: a micro-level analysis of international outsourcing and wages. Canadian Journal of Economics, 41, 243-270.

Hall, A. R., \& Peixe, F. P. M. (2003). A consistent method for the selection of relevant instruments. Econometrics Reviews, 22, 269-287.

Hayashi, F. (2000). Econometrics. New Jersey: Princeton University Press.

Hijzen A., Görg H., \& Hine R. C. (2005). International outsourcing and the skill structure of labour demand in the United Kingdom. Economic Journal, 115, 861-879.

Katz, L. F., \& Summers, L. H. (1989). Industry rents: evidence and implications. Brookings Papers on Economic Activity, pp. 209-275.

Kohler, W. (2004). International outsourcing and factor prices with multistage production. Economic Journal, 114, 166-185.

Moulton, B. R. (1990). An illustration of a pitfall in estimating the effects of aggregate variables on micro units. Review of Economics and Statistics, 72, 334-338.

Munch, J. R., \& Skaksen, J. R. (2005). Specialization, outsourcing and wages. IZA Discussion Paper No. 1907.

Oi, W. Y., \& Idson, T. L. (1999). Firm size and wages. In A. Ashenfelter, \& D. Card (Eds.), Handbook of labor economics, Vol. 3 (pp. 2165-2214). Amsterdam: Elsevier Science.

Stock, J., \& Yogo, M. (2005). Testing for weak instruments in linear IV regressions. In D.W.K. Andrews, \& J.H. Stock (Eds.), Identification and Inference for Econometric Models: Essays in Honor of Thomas Rothenberg. Cambridge, UK: Cambridge University Press 